Article

\title{
Introducing Mediterranean Lupins in Lambs' Diets: Effects on Growth and Digestibility
}

\author{
Mariana Almeida ${ }^{1,2, *}$, Sofia Garcia-Santos ${ }^{2,3}$, Ana Nunes ${ }^{2}$, Sara Rito ${ }^{4}$, Jorge Azevedo ${ }^{1,2}\left(\right.$, Cristina Guedes ${ }^{1,2}(\mathbb{D}$, \\ Severiano Silva ${ }^{1,2}$ and Luís Ferreira ${ }^{2,3}$ (1) \\ 1 Veterinary and Animal Research Centre (CECAV), University of Trás-os-Montes e Alto Douro, \\ Quinta de Prados, 5000-801 Vila Real, Portugal; jazevedo@utad.pt (J.A.); cguedes@utad.pt (C.G.); \\ ssilva@utad.pt (S.S.) \\ 2 Department of Zootechnics, University of Trás-os-Montes e Alto Douro, Quinta de Prados, \\ 5000-801 Vila Real, Portugal; ssantos@utad.pt (S.G.-S.); ananuness94@hotmail.com (A.N.); lmf@utad.pt (L.F.) \\ 3 Centre for the Research and Technology Agro-Environmental and Biological Sciences (CITAB), \\ University of Trás-os-Montes e Alto Douro, Quinta de Prados, 5000-801 Vila Real, Portugal \\ 4 Instituto Superior de Agronomia, School of Agriculture, University of Lisbon, Tapada da Ajuda, \\ 1349-017 Lisbon, Portugal; sara_rito@hotmail.com \\ * Correspondence: mdantas@utad.pt
}

Simple Summary: Finding alternative protein sources has been one of the most important issues in the animal nutrition field in the last decades. Due to its chemical composition and previously reported positive results on lambs' performance and digestibility, lupins were the main focus of this study. Data were collected from two distinct trials with seven different diets tested in total. The chemical composition of the raw materials was analyzed, as well as total dry matter, hay dry matter, and crude protein intake. Lambs' growth was accompanied throughout the trials and their performance was measured. Dry matter, organic matter, and NDF digestibility of each diet was also determined. Low incorporations of lupins had no impact on performance and digestibility of any of the studied fractions. The highest tested incorporation had a negative impact on the overall values of feed intake and the NDF digestibility. The results of this study suggest that low inclusions might have no impact on lambs' growth, intake, and digestibility.

Mediterranean Lupins in Lambs

Diets: Effects on Growth and

Digestibility. Animals 2021, 11, 942.

https://doi.org/10.3390/ani11040942

Academic Editor: Nassim Moula

Received: 10 February 2021

Accepted: 24 March 2021

Published: 26 March 2021

Publisher's Note: MDPI stays neutral with regard to jurisdictional claims in published maps and institutional affiliations.

Abstract: Lupins are suitable candidates to replace soybean meal in livestock feeding in the Mediterranean area, presenting a solution for the European Union's dependence on soybean importations. This study aimed to assess the effect of incorporating Lupinus albus and Lupinus luteus into Churra da Terra Quente lambs' diets on growth performance and digestibility. Two trials were conducted over two years. In trial 1, two experimental diets containing $50 \mathrm{~g} / \mathrm{kg}$ Lupinus albus and $50 \mathrm{~g} / \mathrm{kg}$ Lupinus luteus were tested. In trial 2, lambs were fed with diets containing higher incorporations of Lupinus luteus (100, 150, and $200 \mathrm{~g} / \mathrm{kg}$ : LL10, LL15, and LL20, respectively). Total dry matter, hay dry matter, and crude protein intake were calculated, as well as average daily gains. At the end of the growth trials, dry matter, organic matter, and NDF digestibility was determined. Incorporating $50 \mathrm{~g} / \mathrm{kg}$ of lupins did not affect $(p>0.05)$ the performance. Lambs fed on LL20 diets presented the lowest HDMI and CPI values $(p<0.05)$. The highest intakes $(p<0.05)$ were observed from LL15 lambs. No differences were found in apparent digestibility coefficients between diets $(p>0.05)$, except for NDF digestibility which was highest $(p<0.05)$ for LL20. The optimum level of lupin inclusion in lambs diets seems to be $150 \mathrm{~g} / \mathrm{kg}$.

Keywords: lambs; lupins; growth performance; digestibility

\section{Introduction}

Research in the last decades has been focused on creating solutions and providing alternative protein sources to animal feeding diminishing the European Union (EU) dependence on importing soybean [1]. Overall, lupin grains have only a slightly lower protein 
content (350-400 g/kg DM) [2] compared to soybean meal ( $440 \mathrm{~g} / \mathrm{kg}$ DM) [3] and are very well adapted to the Mediterranean conditions, being ideal for low-input cropping systems and crop rotation $[1,3]$. This makes them suitable candidates to partially or totally replace soybean meal in livestock feeding. Although the introduction of these legume grains into livestock diets has been discussed in the last decades [4,5], recently, it gained higher visibility due to an increasing awareness from the consumers towards the provenience of animal feed [6,7]. The introduction of white (Lupinus albus) and narrow-leafed lupin (Lupinus angustifolius) in ruminant feeding, for example, has been widely studied over the years [8,9] also in in vitro studies [10]. Besides the positive results found on growth performance [11-13], lupin incorporation in sheep feeds has been reported to be an appropriate supplement to increase reproductive performance $[14,15]$. Although traditionally used for grazing sheep in Portugal and other Mediterranean countries [16], few studies have tested the incorporation of yellow lupin (Lupinus luteus) on ruminant feeding. Sheep native breeds, associated with pasture systems, are seen as a solution for reducing livestock emissions [17], and so it becomes even more relevant to study different feeding alternatives.

This study aimed to assess the effect of the inclusion of Lupinus albus and Lupinus luteus grains into Churra da Terra Quente lambs' diets' effect on growth performance and digestibility.

\section{Materials and Methods}

Trial 1 was performed to better understand the effect of introducing small percentages of Lupinus albus and Lupinus luteus in sheep feeding. Based on these results, a second trial was designed to evaluate the effect of increasing the percentage of Lupinus luteus in diets on lamb's growth performance and digestibility. Both trials were conducted in the animal facilities of the University of Trás-os-Montes and Alto Douro (UTAD) at Vila Real (Portugal), and the animals were handled according to the Portuguese law on animal welfare in experimental research [18]. The protocol was approved by the ORBEA (Animal Welfare Body) of the University Trás-os-Montes and Alto Douro (669-e-DZ-2018).

\subsection{Animals and Housing}

The two trials were performed on a total of 28 Churra da Terra Quente male lambs. In trial 1, twelve lambs with initial body weight (BW) of $18 \pm 2.8 \mathrm{~kg}$ and ages between 92 and 110 days were divided into three groups of four animals each. In trial 2, sixteen lambs with initial body weight (BW) of $16 \pm 2.59 \mathrm{~kg}$ and ages between 92 and 110 days were divided into four groups of four animals each. In both trials, the animals were randomly assigned to the groups. All animals were kept in group pens $(2 \times 4 \mathrm{~m}$ each pen) for the entire duration of the growth trials, with access to a feeder per lamb $(40 \mathrm{~cm}$ width) and a water cup per pen ( $24 \mathrm{~cm}$ diameter). During the trials, ambient temperature and humidity were controlled $\left(20 \pm 3{ }^{\circ} \mathrm{C}, 50 \pm 5 \%\right.$, respectively), and the animals were exposed to a natural lighting cycle ( $11 \mathrm{~h}$ light $/ 13 \mathrm{~h}$ dark).

\subsection{Diets}

In trial 1, each group was provided with a different diet: A control diet $(C, 150 \mathrm{~g} / \mathrm{kg}$ soybean meal) with no lupin incorporation, a diet with $50 \mathrm{~g} / \mathrm{kg}$ Lupinus luteus $\mathrm{cv}$. Mister (LL5) and a diet with $50 \mathrm{~g} / \mathrm{kg}$ Lupinus albus cv. Nacional (LA5) (Table 1). The same experimental design was used in trial 2: One group was provided with a control diet (C, $150 \mathrm{~g} / \mathrm{kg}$ soybean meal) and the other three groups were fed with a different level of Lupinus luteus cv. Mister (100 g/kg, 150 g/kg, 200 g/kg; LL10, LL15, LL20, respectively) (Table 1). 
Table 1. Levels of components ( $\mathrm{g} / \mathrm{kg}$ as fed) and chemical composition of the ingested diets (g/kg DM) of growing lambs.

\begin{tabular}{|c|c|c|c|c|c|c|c|c|}
\hline \multirow[b]{2}{*}{ Diets } & \multicolumn{5}{|c|}{ Diet Components } & \multicolumn{3}{|c|}{ Chemical Composition } \\
\hline & $\begin{array}{c}\text { Soybean } \\
\text { Meal }\end{array}$ & Wheat & $\begin{array}{l}\text { Lupinus } \\
\text { albus }\end{array}$ & $\begin{array}{l}\text { Lupinus } \\
\text { luteus }\end{array}$ & Hay & DM & $\mathbf{C P}$ & NDF \\
\hline \multicolumn{9}{|l|}{ Trial 1} \\
\hline C & 150 & 20 & 0 & 0 & 830 & 930 & 121 & 637 \\
\hline LL5 & 100 & 20 & 0 & 50 & 830 & 933 & 117 & 629 \\
\hline LA5 & 100 & 20 & 50 & 0 & 830 & 923 & 114 & 632 \\
\hline \multicolumn{9}{|l|}{ Trial 2} \\
\hline $\mathrm{C}$ & 170 & 20 & 0 & 0 & 810 & 929 & 130 & 626 \\
\hline LL10 & 100 & 20 & 0 & 100 & 780 & 925 & 127 & 621 \\
\hline LL15 & 50 & 20 & 0 & 150 & 780 & 937 & 128 & 628 \\
\hline LL20 & 0 & 20 & 0 & 200 & 780 & 941 & 128 & 628 \\
\hline
\end{tabular}

Lupinus luteus $150 \mathrm{~g} / \mathrm{kg}$, LL20_Lupinus luteus $200 \mathrm{~g} / \mathrm{kg}$, DM-Dry Matter, CP-Crude Protein, NDF-Neutral Detergent Fiber.

White (Lupinus albus cv. Nacional) and yellow lupin (Lupinus luteus cv. Mister) grains, wheat, and soybean meal were acquired from a local company and analyzed for their chemical composition (Table 2). Lamb growth requirements were calculated according to AFRC [19] recommendations. Diets were formulated to be isonitrogenous (11-13\% CP) and isoenergetic ( $9 \mathrm{MJ} \mathrm{kg}^{-1} \mathrm{DM}$ ), according to Kirchgessner and Kellner [20]. The animals had an adaptation period of 21 days before each trial. After that, the ingested quantities were adjusted to the lambs' growth requirements. The concentrate feeds were weighed, provided, and controlled daily and individually. The lambs had access to meadow hay and water ad libitum during both trials. Meadow hay was milled roughly around $4 \mathrm{~cm}$ and lupines and wheat were milled at $4 \mathrm{~mm}$. Soybean meal was presented with commercial granulometry. Samples of dietary components were collected once every fifteen days for chemical analysis. The feed refusals were weighed in the morning and then placed in labeled plastic bags. They were subsequently frozen at $-15^{\circ} \mathrm{C}$. At the end of the experimental period, the samples were thawed, homogenized, dried at $55^{\circ} \mathrm{C}$ for $72 \mathrm{~h}$, and then ground to pass through a 1-mm screen (Tecnal, Piracicaba, São Paulo, Brazil). The ground samples were then stored in properly sealed, airtight, plastic containers (ASS, Ribeirão Preto, São Paulo, Brazil) until needed for laboratory analysis.

Table 2. Chemical composition of diet components (g/kg DM) used in both trials.

\begin{tabular}{|c|c|c|c|c|c|c|c|c|c|}
\hline \multirow{2}{*}{ Raw Materials } & \multicolumn{9}{|c|}{ Chemical Composition } \\
\hline & DM & OM & $\mathrm{CP}$ & EE & NDF & ADF & ADL & Soluble Sugars & Starch \\
\hline Lupinus albus & 954 & 963 & 347 & 75.5 & 220 & 181 & 13.9 & 50.1 & 1.7 \\
\hline Lupinus luteus & 954 & 954 & 431 & 40.2 & 257 & 199 & 9.7 & 40.6 & 7.2 \\
\hline $\begin{array}{l}\text { Soybean meal } \\
\text { (Trial 1) }\end{array}$ & 888 & 930 & 510 & 14.5 & 162 & 82.7 & 4.0 & 98.6 & 10.5 \\
\hline $\begin{array}{l}\text { Soybean meal } \\
\text { (Trial 2) }\end{array}$ & 887 & 929 & 510 & 13.8 & 161 & 82.6 & 3.1 & 96.2 & 9.9 \\
\hline Wheat & 867 & 984 & 109 & 18.2 & 128 & 29.3 & 6.4 & 4 & 640 \\
\hline $\begin{array}{c}\text { Hay } \\
\text { (Trial 1) }\end{array}$ & 939 & 931 & 51.0 & 7.7 & 736 & 504 & 75.2 & 9.4 & 8.0 \\
\hline $\begin{array}{c}\text { Hay } \\
\text { (Trial 2) }\end{array}$ & 929 & 921 & 50.8 & 7.1 & 730 & 465 & 72.4 & 9.1 & 7.6 \\
\hline
\end{tabular}

DM-Dry Matter, OM-Organic matter, CP—Crude Protein, EE-Ether Extract, NDF-Neutral Detergent Fiber, ADF-Acid Detergent Fiber, ADL—Acid Detergent Lignin.

\subsection{Growth Trials}

Before the beginning of the experiments, the lambs had an adaptation period of 21 days in which they were gradually introduced to the pens and diets. Animals were 
weighed using a scale (Kern HUS 150K50, KERN \& Sohn GmbH, Balingen, Germany) at the beginning of the trial and then weekly, always before the first meal of the day, and average daily gains (ADG) were calculated considering the differences of weight between each week for each lamb. Feed conversion ratios (FCR) were obtained by dividing the daily hay and concentrate intake by the ADG. Concentrate and hay refusal data were collected daily. Since hay was offered ad libitum to each group, hay intake was estimated for each lamb each day based on their refusals and hay dry matter intake (HDMI) was calculated. Total dry matter intake (DMI), neutral detergent fiber intake (NDFI), and crude protein intake (CPI) were calculated based on the estimated hay intake and individual concentrate intake. Both trials lasted 12-16 weeks and finished as soon as all the lambs achieved a BW of approximately $25-27 \mathrm{~kg}$.

\subsection{Digestibility Trials}

At the end of the growth trials, all the animals were transferred to individual metabolic cages. The lambs were fed once a day with the same diets they had previously been receiving, restricted to their maintenance levels [19] (Table 3). Daily intakes were controlled, and feed refusals were registered daily. After an adaptation period of 5 days, feces were collected for 7 days. Feces were collected daily, weighed, and stored at $-17^{\circ} \mathrm{C}$ in plastic containers. After homogenization, two samples from each lamb were collected and dried at $70{ }^{\circ} \mathrm{C}$ for $48 \mathrm{~h}$. Samples were milled and analyzed for dry matter, organic matter, and NDF. Dry matter, organic matter, and NDF apparent digestibilities were obtained using the general formula presented by Mcdonald et al. [21]:

$$
\frac{\text { Fraction consumed }- \text { Fraction in feces }}{\text { Fraction consumed }} \times 100
$$

Table 3. Levels of components $(\mathrm{g} / \mathrm{kg}$ as fed) ingested during the digestibility trials.

\begin{tabular}{|c|c|c|c|c|c|}
\hline \multirow[b]{2}{*}{ Diets } & \multicolumn{5}{|c|}{ Chemical Composition } \\
\hline & Soybean Meal & Wheat & Lupinus albus & Lupinus luteus & Hay \\
\hline \multicolumn{6}{|l|}{ Trial 1} \\
\hline $\mathrm{C}$ & 125 & 0 & 0 & 0 & 500 \\
\hline LL5 & 90 & 0 & 0 & 40 & 500 \\
\hline LA5 & 105 & 0 & 30 & 0 & 500 \\
\hline \multicolumn{6}{|l|}{ Trial 2} \\
\hline C & 70 & 10 & 0 & 0 & 500 \\
\hline LL10 & 30 & 10 & 0 & 30 & 500 \\
\hline LL15 & 15 & 10 & 0 & 45 & 500 \\
\hline LL20 & 0 & 10 & 0 & 90 & 500 \\
\hline
\end{tabular}

\subsection{Chemical Composition}

Samples from all the diet components and feces were milled at 1 and $0.5 \mathrm{~mm}$ (Retsch cutting mill, model SM1, Retsch GmbH, Haan, Germany) and analyzed through AOAC [22] procedures for dry matter (DM) (934.01), organic matter (OM) (942.05), ether extract (EE) (920.39), crude protein (CP) (954.01), and starch (996.11). A Velp Scientifica apparatus (Velp Scientifica srl, Usmate, Italy) was used to determine Kjedhal N, which was then multiplied by a conversion factor of 6.25 to determine $\mathrm{CP}$ content. A solvent recovery extractor for oils and fats (JP Selecta, Det-Gras N, Barcelona, Spain) was used to determine EE content. To determine starch content, an enzymatic kit K-TSTA-100A (Megazyme, Enterprise Ireland, Dublin, Ireland) and a spectrometer UVmin-1240 (Shimadzu, Quioto, Japan) were used. Neutral detergent fiber (NDF) and acid detergent fiber (ADF) were obtained through the Robertson and Van Soest and Van Soest et al. [23,24] methodologies. Acid detergent lignin (ADL) was determined by solubilization of cellulose with sulfuric acid [23]. Soluble sugar content was determined using a UV-VIS spectrophotometry UVmin-1240 (Shimadzu, Quioto, Japan; $625 \mathrm{~nm}$ ) through the anthrone methodology [25]. 


\subsection{Statistical Analyses}

Statistical analysis was performed on IBM SPSS ${ }^{\circledR}$, version 27 [26]. Prior to analysis, data were checked for normality and homogeneity using Shapiro-Wilk and Levene tests. Since results did not satisfy the assumptions of normality and transformations were ineffective, data from the growth trials were then subjected to a Friedman test. A Kruskal-Wallis test was performed on digestibility data. Whenever significant differences were found, the data were subjected to a pair-wise Wilcoxon-Mann-Whitney test to establish levels of difference. Diets were used as the main factor, and significance was declared at $p<0.05$. Despite not satisfying the assumptions of normality, data from the growth trial in trial 2 were tested for linear and quadratic contrasts since different levels of inclusion were being compared.

\section{Results}

\subsection{Growth Trials}

No palatability problems were observed in all the treatments involving lupin incorporation during both trials. The inclusion of small percentages of lupins had no effect $(p>0.05)$ on intake or growth, as is shown by the results of trial 1 (Table 4$)$.

Table 4. Intake and growth performance (g/day) of growing lambs in trial 1.

\begin{tabular}{|c|c|c|c|c|c|}
\hline \multirow{2}{*}{ Parameters } & \multicolumn{3}{|c|}{ Diets } & \multirow{2}{*}{ SEM } & \multirow{2}{*}{$p$} \\
\hline & $\mathrm{C}(n=4)$ & $\operatorname{LL5}(n=4)$ & LA5 $(n=4)$ & & \\
\hline ADG & 125 & 151 & 122 & 15.1 & 0.936 \\
\hline FCR & 5.8 & 5.0 & 6.1 & 0.59 & 0.825 \\
\hline DMI & 702 & 710 & 717 & 12.1 & 0.682 \\
\hline HDMI & 566 & 566 & 569 & 11.3 & 0.682 \\
\hline NDFI & 436 & 443 & 444 & 8.5 & 0.392 \\
\hline CPI & 91.0 & 91.6 & 90.9 & 1.23 & 0.682 \\
\hline
\end{tabular}

C-Control, LL5-Lupinus luteus $50 \mathrm{~g} / \mathrm{kg}$, LA5-Lupinus albus $50 \mathrm{~g} / \mathrm{kg}$, ADG-Average Daily Gain, FCR-Feed Conversion Rate, DMI-Total Dry Matter Intake, HayDMI-Hay Dry Matter Intake, NDFI-Neutral Detergent Fiber Intake, CPI-Crude Protein Intake, SEM-standard error of the mean.

Higher inclusions of Lupinus luteus and total replacement of soybean meal had no impact $(p>0.05)$ on growth performance (Table 5). ADG values were comparable between $C$ groups of both trials. Lambs from group LL20 presented the lowest HDMI values $(p<0.05)$. Concerning protein intake $(\mathrm{CPI})$, there were similarities between groups $\mathrm{C}$ and LL15, which presented superior values $(p<0.05)$ than LL10 and LL20. Hay ingestion (HDMI) was around $60 \mathrm{~g} /$ day lower $(p<0.05)$ for LL20 when compared to C and LL15 groups. These groups presented the highest HDMI values. There seems to be no linear or quadratic trend in most of the data from the growth trials $(p>0.05)$, except for HDMI $(p=0.029)$ and CPI $(p=0.016)$, which show a linear trend.

Table 5. Intake and growth performance (g/day) of growing lambs in trial 2.

\begin{tabular}{|c|c|c|c|c|c|c|}
\hline \multirow{2}{*}{ Parameters } & \multicolumn{4}{|c|}{ Diets } & \multirow{2}{*}{ SEM } & \multirow{2}{*}{$p$} \\
\hline & $\mathrm{C}(n=4)$ & $\operatorname{LL10}(n=4)$ & $\operatorname{LL15}(n=4)$ & $\operatorname{LL20}(n=4)$ & & \\
\hline ADG & 116 & 96.0 & 104 & 95.2 & 7.6 & 0.198 \\
\hline FCR & 6.5 & 7.5 & 7.4 & 7.4 & 0.60 & 0.145 \\
\hline DMI & $735^{a, b}$ & $705^{b}$ & $755^{a}$ & $690^{b}$ & 14.6 & 0.019 \\
\hline HDMI & $556^{\mathrm{a}}$ & $526^{a}$ & $557^{\mathrm{a}}$ & $493^{b}$ & 14.0 & 0.019 \\
\hline NDFI & $441^{\mathrm{a}, \mathrm{b}}$ & $423^{b}$ & $460^{a}$ & $409^{b}$ & 10.4 & 0.038 \\
\hline CPI & $108^{a}$ & $104^{\mathrm{b}}$ & $108^{a}$ & $104^{b}$ & 0.9 & 0.019 \\
\hline
\end{tabular}

ADG_-Average Daily Gain, FCR_Feed Conversion Rate, DMI-Total Dry Matter Intake, HDMI-Hay Dry Matter Intake, NDFI-Neutral Detergent Fiber Intake, CPI—Crude Protein Intake, SEM-standard error of the mean. Different superscript letters $(a, b)$ on the same row indicate significant differences $(p<0.05)$. 


\subsection{Digestibility Trials}

One lamb from trial 1 died before the beginning of digestibility trials, so only three animals from $C$ group remained. In trial 1 , no differences were found in apparent digestibility coefficients (Table 6). Lambs from LL15 and LL20 presented the highest NDFD digestibility (659.15 and $661.45 \mathrm{~g} / \mathrm{kg}$, respectively; Table 7).

Table 6. Apparent digestibility coefficients $(\mathrm{g} / \mathrm{kg})$ of growing lambs in trial 1.

\begin{tabular}{|c|c|c|c|c|c|}
\hline \multirow{2}{*}{ Digestibility } & \multicolumn{3}{|c|}{ Diets } & \multirow{2}{*}{ SEM } & \multirow{2}{*}{$p$} \\
\hline & $C(n=3)$ & $\operatorname{LL5}(n=4)$ & LA5 $(n=4)$ & & \\
\hline DMD & 692 & 648 & 656 & 32.9 & 0.591 \\
\hline OMD & 705 & 664 & 675 & 30.1 & 0.565 \\
\hline NDFD & 686 & 626 & 638 & 24.4 & 0.149 \\
\hline
\end{tabular}

C-Control, LL5-Lupinus luteus 50 g/kg, LA5—Lupinus albus 50 g/kg, DMD—Dry Mater Apparent Digestibility, OMD—Organic Matter Apparent Digestibility, NDFD—Neutral Detergent Fiber Apparent Digestibility, SEMstandard error of the mean.

Table 7. Apparent digestibility coefficients $(\mathrm{g} / \mathrm{kg})$ of growing lambs in trial 2.

\begin{tabular}{ccccccc}
\hline \multirow{2}{*}{ Digestibility } & \multicolumn{9}{c}{ Diets } & \multirow{2}{*}{ SEM } & $p$ \\
\cline { 2 - 5 } & $\mathbf{C}(\boldsymbol{n}=\mathbf{4})$ & $\mathbf{L L 1 0}(\boldsymbol{n = 4 )}$ & $\mathbf{L L 1 5}(\boldsymbol{n = 4 )}$ & $\mathbf{L L 2 0}(\boldsymbol{n = 4 )}$ & & \\
\hline DMD & 640 & 649 & 661 & 677 & 10.5 & 0.228 \\
OMD & 658 & 663 & 682 & 694 & 10.0 & 0.087 \\
NDFD & $624^{\mathrm{b}}$ & $632^{\mathrm{b}}$ & $659^{\mathrm{a}}$ & $662^{\mathrm{a}}$ & 10.5 & 0.037 \\
\hline
\end{tabular}

C-Control, LL10—Lupinus luteus $100 \mathrm{~g} / \mathrm{kg}$, LL15—Lupinus luteus $150 \mathrm{~g} / \mathrm{kg}$, LL20—Lupinus luteus $200 \mathrm{~g} / \mathrm{kg}$, DMD—Dry Mater Apparent Digestibility, OMD—Organic Matter Apparent Digestibility, NDFD—Neutral Detergent Fiber Apparent Digestibility, SEM—standard error of the mean. Different superscript letters $(a, b)$ on the same row indicate significant differences $(p<0.05)$.

\section{Discussion}

As expected, lupins used in this study presented high levels of $\mathrm{CP}$, as well as fiber fraction values, and negligible amounts of starch, as described by other authors [27,28], although other authors [28] have reported lower CP values (362 g/ $\mathrm{kg} \mathrm{DM)} \mathrm{for} \mathrm{Lupinus}$ luteus cv. Mister. The results obtained in the first trial suggest that low inclusions of both lupin species ( $50 \mathrm{~g} / \mathrm{kg}$ as fed) have no effect $(p>0.05)$ on any of the studied parameters. These results are consistent with those observed in previous studies, which have reported no differences $(p>0.05)$ in ADG, intakes, and feed efficiency in lambs [11-13,29] with lupin inclusion to their feed. Fychan et al. [30] observed no differences $(p>0.05)$ in ADG of Suffolk castrated lambs fed 23\% narrow-leafed lupin (Lupinus angustifolius) and 16\% yellow lupin (Lupinus luteus), which is consistent with our results in both trials. However, other studies have reported the effects of higher inclusion of lupin seeds on ADG [11,12,31]. Lower than desirable amounts of methionine in lupins paired with the fact that low proportions of these amino acids bypass rumen degradation to reach the small intestine could affect ruminant's performance [4,13], especially at high levels of feeding, which might explain lower values of ADG if diets only adjusted to be isonitrogenous and not for amino acid profile.

Overall, increasing lupin inclusion levels in lambs' diets led to a reduced HDMI $(p<0.05)$, around 32-63 g/day less than the other groups. Since lupins present higher fiber levels than soybean meal, lambs from LL20 may have compensated for this with reduced hay intake. In a study by Lestingi et al. [31] with Gentile di Puglia male lambs, the inclusion of $250 \mathrm{~g} / \mathrm{kg}$ of Lupinus albus $\mathrm{cv}$. Multitalia significantly reduced $(p<0.01)$ the average daily feed intake when compared to another faba bean (Vicia faba L.) and peas (Pisum sativum L.) (690 vs. 740 and $770 \mathrm{~g} /$ day). In contrast, White et al. [12] have reported no statistical differences $(p>0.01)$ between $35 \%$ and $70 \%$ lupin inclusion on the diets, although DMI reduced with increased incorporations (1123 and $1056 \mathrm{~g} /$ day, respectively). Our study presents lower $(p<0.05)$ HDMI intakes for LL20 with no effect $(p>0.05)$ on 
lambs' performance. Antinutritional components, such as alkaloids, which have a negative effect on palatability and therefore on ingestion $[4,28,32]$, were present at a very low level. Considering these levels and the fact that the lambs showed no aversion when provided the concentrate feed, consuming all of it every day, it is safe to assume that the scarce presence of bitter components did not reduce intakes.

As happened with performance traits, digestibility seems to suffer no alterations with small lupin inclusions in the diet. However, the two highest lupin inclusions in this study (LL15 and LL20) had an effect $(p<0.05)$ on NDF digestibility, which was higher at these levels. Higher inclusions of lupin grains (75\% vs. $35 \%$ ) in Merino weaner sheep diets have provided similar results, with an increase $(p<0.01)$ of OMD proportional to the level of lupins in the diet [12]. Ephrem et al. [33] reported higher DM and OM apparent digestibility $(p<0.05)$ in Washera lambs supplemented with sweet lupin grains, between 682 and $715 \mathrm{~g} / \mathrm{kg}$. Higher intakes generally result in increases in the passage rate of digesta, due to a lower exposure to digestive enzymes [21], however, in this study, there was no effect $(p>0.05)$ of diet on DMD and OMD.

\section{Conclusions}

The inclusion of lupins in diets of growing lambs had no significant effect on growth performance and digestibility, although there was an effect on forage intake. We hypothesize that $150 \mathrm{~g} / \mathrm{kg}$ inclusion of lupins in the diet may be an optimum value since it presented the best results, especially considering the aim of this study was maximum soybean meal replacement. Total replacement of soybean meal resulted in worse intake results due to reduced hay intake, but it did not affect performance.

Overall, lupins seem to be a possible solution to replace soybean meal in lambs grown in the Mediterranean region. Ideally, higher incorporations would need to be studied, as well as a higher number of animals, to draw further conclusions.

Author Contributions: Conceptualization, C.G., L.F., S.S. and J.A.; methodology, C.G., L.F., S.S., M.A., S.G.-S.; software, M.A. and L.F.; investigation, M.A., S.G.-S., A.N. and S.R.; resources, C.G. and L.F; writing —original draft preparation, M.A.; writing—review and editing, M.A., S.G.-S., A.N., S.R., J.A., C.G., S.S., L.F.; supervision, L.F., C.G. and S.S.; project administration, C.G.; funding acquisition, C.G. All authors have read and agreed to the published version of the manuscript.

Funding: The authors acknowledge financial support through project INTERACT—“Integrative Research in Environment, Agro-Chains and Technology", reference NORTE-01-0145-FEDER-000017, in its line of research entitled ISAC, co-financed by the European Regional Development Fund through NORTE 2020 (North Regional Operational Program 2014/2020). For authors integrated into the research unit CECAV, research was further financed by the National Funds from FCT, the Portuguese Foundation for Science and Technology, project number UIDB/CVT/00772/2020.

Institutional Review Board Statement: The study was conducted according to the guidelines of the the protocol approved by the ORBEA (Animal Welfare Body) of the University Trás-os-Montes and Alto Douro (669-e-DZ-2018).

Informed Consent Statement: Not applicable.

Data Availability Statement: The data presented in this study are available on request from the corresponding author. The data are not publicly available to preserve privacy of the data.

Acknowledgments: The authors thank and acknowledge the University of Trás-os-Montes and Alto Douro experimental farm and animal nutrition laboratory staff.

Conflicts of Interest: The authors declare no conflict of interest.

\section{References}

1. Watson, C.A.; Reckling, M.; Preissel, S.; Bachinger, J.; Bergkvist, G.; Kuhlman, T.; Lindström, K.; Nemecek, T.; Topp, C.F.; Vanhatalo, A.; et al. Grain Legume Production and Use in European Agricultural Systems. In Advances in Agronomy; Elsevier BV: Amsterdam, The Netherlands, 2017; Volume 144, pp. 235-303. 
2. Day, L. Proteins from land plants-Potential resources for human nutrition and food security. Trends Food Sci. Technol. 2013, 32, 25-42. [CrossRef]

3. Gresta, F.; Wink, M.; Prins, U.; Abberton, M.; Capraro, J.; Scarafoni, A.; Hill, G. Lupins in European cropping systems. In Legumes in Cropping Systems; CABI Publishing: Egham, UK, 2017; pp. 88-108.

4. Van Barneveld, R.J. Understanding the nutritional chemistry of lupin (Lupinus spp.) seed to improve livestock production efficiency. Nutr. Res. Rev. 1999, 12, 203-230. [CrossRef] [PubMed]

5. Martín-Pedrosa, M.; Varela, A.; Guillamón, E.; Cabellos, B.; Burbano, C.; Gomez-Fernandez, J.; De Mercado, E.; Gomez-Izquierdo, E.; Cuadrado, C.; Múzquiz, M. Biochemical characterization of legume seeds as ingredients in animal feed. Span. J. Agric. Res. 2016, 14, e0901. [CrossRef]

6. Troy, D.; Kerry, J. Consumer perception and the role of science in the meat industry. Meat Sci. 2010, 86, 214-226. [CrossRef] [PubMed]

7. Hartmann, C.; Siegrist, M. Consumer perception and behaviour regarding sustainable protein consumption: A systematic review. Trends Food Sci. Technol. 2017, 61, 11-25. [CrossRef]

8. Hill, G.D. Lupins in sheep nutrition. In Proceedings of the 5th International Lupin Conference, Poznan, Poland, 5-8 July 1988; pp. 359-372.

9. Tadele, Y. White lupin (Lupinus albus) grain, a potential source of protein for ruminants: A review. Res. J. Agric. Environ. Manag. 2015, 4, 2315-8719.

10. Calabrò, S.; Tudisco, R.; Balestrieri, A.; Piccolo, G.; Infascelli, F.; Cutrignelli, M.I. Fermentation characteristics of different grain legumes cultivars with the invitro gas production technique. Ital. J. Anim. Sci. 2009, 8, 280-282. [CrossRef]

11. Kung, L.; Maciorowski, K.; Powell, K.M.; Weidner, S.; Eley, C.L. Lupin as a protein supplement for growing lambs. J. Anim. Sci. 1991, 69, 3398-3405. [CrossRef] [PubMed]

12. White, C.; Hanbury, C.; Young, P.; Phillips, N.; Wiese, S.; Milton, J.; Davidson, R.; Siddique, K.; Harris, D. The nutritional value of Lathyrus cicera and Lupinus angustifolius grain for sheep. Anim. Feed Sci. Technol. 2002, 99, 45-64. [CrossRef]

13. Wiese, S.C.; White, C.L.; Masters, D.G.; Milton, J.T.B.; Davidson, R.H. Growth and carcass characteristics of prime lambs fed diets containing urea, lupins or canola meal as a crude protein source. Aust. J. Exp. Agric. 2003, 43, 1193-1197. [CrossRef]

14. Brien, F.D.; Cumming, I.A.; Baxter, R.W. Effect of feeding a lupin grain supplement on reproductive performance of maiden and mature ewes. J. Agric. Sci. 1977, 89, 437-443. [CrossRef]

15. Nottle, M.; Kleemann, D.; Grosser, T.; Seamark, R. Evaluation of a nutritional strategy to increase ovulation rate in merino ewes mated in late spring-early summer. Anim. Reprod. Sci. 1997, 47, 255-261. [CrossRef]

16. Pinto, P.A. The role of Lupinus luteus in a Portuguese environment friendly agroforestry system. In Advances in Lupin Research; Neves Martins, J.M., Beirão da Costa, L., Eds.; ISA Press: Lisbon, Portugal, 1994; pp. 290-295. [CrossRef]

17. Stampa, E.; Schipmann-Schwarze, C.; Hamm, U. Consumer perceptions, preferences, and behavior regarding pasture-raised livestock products: A review. Food Qual. Prefer. 2020, 82, 103872. [CrossRef]

18. Decree-Law No. 1/2019 Amending Decree-Law No. 113/2013 Implementing EU Directive No. 2010/63 on Animal Protection for Scientific Purposes, Government of Portugal. Available online: http:/ /www.fao.org/faolex/results/details/en/c/LEX-FAOC1 83382 (accessed on 5 January 2021).

19. AFRC. Energy and Protein Requirements of Ruminants. In An Advisory Manual Prepared by the AFRC Technical Committee on Responses to Nutrients; CAB International: Wallingford, UK, 1993.

20. Kirchgessner, M.; Kellner, R.J. Zur Schätzung energetischer Futterwerte von Mischfutter- mitteln für Rinder. Tierernaehr. Futterm. 1981, 45, 9-16. [CrossRef]

21. McDonald, P.; Edwards, R.A.; Green Halsh, J.F.D.; Morgan, C.A. Animal Nutrition 2011, 7th ed.; Prentice Hall: London, UK, 2011.

22. Association of Official Analytical Chemists (AOAC). Official Methods of Analysis 2006, 18th ed.; Association of Official Analytical Chemists: Gaithersburgs, MD, USA, 2006.

23. Robertson, J.B.; Van Soest, P.J. The detergent system of analysis and its application to human foods. In The Analysis of Dietary Fiber in Food; James, W.P.T., Theander, O., Eds.; Marcel Dekker: New York, NY, USA, 1981; pp. 123-158.

24. Van Soest, P.V.; Robertson, J.B.; Lewis, B.A. Methods for Dietary Fiber, Neutral Detergent Fiber, and Nonstarch Polysaccharides in Relation to Animal Nutrition. J. Dairy Sci. 1991, 74, 3583-3597. [CrossRef]

25. Irigoyen, J.J.; Einerich, D.W.; Sanchez-Diaz, M. Water stress induced changes in concentrations of proline and total soluble sugars in nodulated alfalfa (Medicago sativd) plants. Physiol. Plant. 1992, 84, 55-60. [CrossRef]

26. IBM Corp. IBM SPSS Statistics for Windows, Version. Available online: https://www.ibm.com/analytics/spss-statistics-software (accessed on 5 January 2021).

27. Institut National de la Recherche Agronomique (INRA). INRA Feeding System for Ruminants; Wageningen Academic Publishers: Wageningen, The Netherlands, 2018; p. 640.

28. National Research Council. Nutrient Requirements of Dairy Cattle, 7th ed.; National Academies Press: Washington, DC, USA, 2001.

29. Musco, N.; Cutrignelli, M.I.; Calabrò, S.; Tudisco, R.; Infascelli, F.; Grazioli, R.; Presti, V.L.; Gresta, F.; Chiofalo, B. Comparison of nutritional and antinutritional traits among different species (Lupinus albus L., Lupinus luteus L., Lupinus angustifolius L.) and varieties of lupin seeds. J. Anim. Physiol. Anim. Nutr. 2017, 101, 1227-1241. [CrossRef] [PubMed] 
30. Fychan, R.; Marley, C.; Lewis, G.; Davies, R.; Theobald, V.; Jones, R.; Abberton, M. Effects of feeding concentrate diets containing narrow-leafed lupin, yellow lupin or soya when compared with a control diet on the productivity of finishing lambs. In Proceedings of the 12th International Lupin Conference-Lupins for Health and Wealth, Fremantle, Australia, 14-18 September 2008; pp. 127-130.

31. Lestingi, A.; Colonna, M.; Marsico, G.; Tarricone, S.; Facciolongo, A. Effects of legume seeds and processing treatment on growth, carcass traits and blood constituents of fattening lambs. S. Afr. J. Anim. Sci. 2019, 49, 799. [CrossRef]

32. Tefera, G.; Tegegne, F.; Mekuriaw, Y.; Melaku, S.; Tsunekawa, A. Effects of different forms of white lupin (Lupinus albus) grain supplementation on feed intake, digestibility, growth performance and carcass characteristics of Washera sheep fed Rhodes grass (Chloris gayana) hay-based diets. Trop. Anim. Health Prod. 2015, 47, 1581-1590. [CrossRef] [PubMed]

33. Ephrem, N.; Tegegne, F.; Mekuriaw, Y.; Yeheyis, L. Nutrient intake, digestibility and growth performance of Washera lambs supplemented with graded levels of sweet blue lupin (Lupinus angustifolius L.) seed. Small Rumin. Res. 2015, 130, 101-107. [CrossRef] 